\title{
PERAMALAN JUMLAH PENUMPANG PESAWAT TERBANG DI PINTU KEDATANGAN BANDAR UDARA INTERNASIONAL PATTIMURA AMBON DENGAN MENGGUNAKAN METODE ARIMA BOX-JENKINS
}

\section{The Forecasting Number of Aircraft Passengers at The International Airport of Pattimura Ambon Using Arima Box-Jenkins Method}

\author{
Sasmita Hayoto', Yopi Andry Lesnussa ${ }^{2}$, Henry W. M. Patty ${ }^{3}$, R. J. Djami ${ }^{4 *}$ \\ ${ }_{1,2,3,4}$ Jurusan Matematika, FMIPA, Universitas Pattimura \\ ${ }^{2}$ Lab. Matematika Terapan, FMIPA, Universitas Pattimura \\ ${ }^{3}$ Lab. Aljabar \& Analisis, FMIPA, Universitas Pattimura \\ ${ }^{4}$ Lab. Statistika, FMIPA, Universitas Pattimura \\ Jln. Ir. M. Putuhena, Kampus Unpatti, Poka-Ambon, 97233, Maluku, Indonesia \\ e-mail :yopi_a_lesnussa@yahoo.com; ${ }^{4 *}$ ronalddjami@gmail.com
}

Corresponding author*

\begin{abstract}
Abstrak
Model Autoregressive integrated moving average (ARIMA) merupakan model yang sering digunakan untuk meramalkan data time series. Pada era globalisasi, perkembangan zaman maju dengan pesat, salah satunya dalam bidang transportasi. Pesawat merupakan salah satu transportasi yang dapat digunakan penduduk untuk menunjang aktifitasnya, baik dalam hal bisnis maupun parawisata.Tujuan penelitian yang ingin dicapai adalah untuk mengetahui peramalan jumlah penumpang pesawat terbang di pintu kedatangan Bandar Udara Internasional Pattimura Ambon dengan menggunakan metode ARIMA Box-Jenkins. Pemilihan model terbaik yaitu ARIMA $(0,1,3)$ karena memiliki nilai parameter yang signifikan dan nilai MSE lebih kecil.
\end{abstract}

Kata Kunci: Peramalan Jumlah Penumpang, Analisis Times Series, ARIMA

Abstract

The Autoregressive Integrated Moving Average (ARIMA) model is often used to forecast time series data. In the era of globalization, rapidly progressing times, one of them in the field of transportation. The aircraft is one of the transportation that the residents can use to support their activities, both in business and tourism. The objective of the research is to know the forecasting of the number of passengers of airplanes at the arrival gate of Pattimura Ambon International Airport using ARIMA Box-Jenkins method. The best model selection is ARIMA $(0,1,3)$ because it has significant parameter value and MSE value is smaller.

Keywords: Forecasting Number of Passengers, Times Series Analysis, ARIMA 


\section{PENDAHULUAN}

Transportasi mempunyai peranan yang sangat penting dan strategis dalam mendukung, mendorong, dan menunjang segala aspek kehidupan. Transportasi dibutuhkan untuk menjamin terselenggaranya mobilitas penduduk maupun barang. Sebagai bagian dari sistem perekonomian, transportasi memiliki fungsi penting dalam pembangunan nasional maupun pembangunan regional. Provinsi Maluku merupakan wilayah kepulauan yang cukup luas di Indonesia. Banyaknya pulau yang menjadi wilayah administrasi Provinsi Maluku, mendorong harus terciptanya sistem transportasi yang mampu menjamin keberlangsungan mobilitas masyarakat agar lebih efektif dan efisien [2].

Seiring dengan bertambahnya jumlah penduduk, maka kebutuhan akan alat transportasi juga meningkat karena alat transportasi juga merupakan sarana penting bagi penduduk untuk melakukan aktifitasnya. Salah satunya alat transportasi udara, yaitu pesawat terbang merupakan sarana yang dapat digunakan penduduk untuk menunjang aktifitasnya, baik dalam hal bisnis maupun parawisata [1].

Bandar Udara Internasional Pattimura dahulu bernama lapangan terbang Laha Ambon yang dibangun pada tahun 1939 oleh pemerintah penjajah belanda yang merupakan perusahaan penyedia jasa transportasi udara di Kota Ambon. Jumlah penumpang pesawat terbang di Bandar Udara Pattimura Ambon mengalami peningkatan, oleh karena itu peramalan tentang jumlah penumpang menjadi hal yang penting bagi perusahaan karena dengan mengetahui peramalan jumlah penumpang di masa yang akang datang perusahaan dapat mempersiapkan fasilitas untuk mengantisipasi kenaikan jumlah penumpang, seperti menyiapkan penerbangan ekstra, ruang tunggu yang lebih nyaman dan tempat parkir yang lebih luas [1].

Dalam meramalkan jumlah penumpang di Bandar Udara Pattimura akan digunakan dalam metode peramalannya yaitu model Autoregressive integrated moving average (ARIMA) merupakan model yang sering di gunakan untuk meramalkan data time series.

Penelitian yang terkait peramalan jumlah penumpang juga pernah dilakukan oleh [4], [6], [8], dan [12]. Sedangkan, penelitian terkait dengan metode ARIMA pernah dilakukan oleh [11].

Berdasarkan latar belakang tersebut diperoleh tujuan dari penelitian ini adalah untuk mengestimasi model terbaik dengan metode ARIMA pada data penumpang pesawat di Bandar Udara Pattimura untuk periode Januari 2010 - Desember 2016.

\section{METODE PENELITIAN}

Penelitian ini menggunakan data sekunder yang diperoleh dari Bandar Udara Internasional Pattimura untuk meramalkan jumlah penumpang pesawat yang dikumpulkan dari SLALU (Statistik Lalu Lintas Udara) PT. Angkasa Pura (Persero). Data yang diambil dari PT Angkasa Pura (Persero) adalah data jumlah kedatangan penumpang pesawat terbang pada penerbangan domestik di Bandar Udara Internasional Pattimura Ambon dalam periode bulanan mulai dari Januari 2010 sampai Desember 2016. Dari data yang diperoleh dilakukan pengolahan data dengan menggunakan software Minitab untuk melakukan peramalan dengan menggunakan metode ARIMA Box-Jenkins.

Dalam tahap analisis data, langkah-langkah yang dilakukan untuk melakukan peramalan dengan metode ARIMA Box-Jenkins adalah

\section{Identifikasi Model}

Pada tahap ini akan mencari atau menentukan p, d dan q. p menunjukan tingkat model autoregressive, $\mathrm{q}$ menunjukan tingkat model moving average dan $\mathrm{d}$ menunjukan banyak differencing yang dilakukan untuk mencari model awal. Penentuan $\mathrm{p}$ dan $\mathrm{q}$ dengan bantuan korelogram autokorelasi $(A C F)$ dan korelogram autokorelasi parsial (PACF) selanjutnya ditentukan tingkat stasioneritasnya. Dalam melakukan identifikasi model langkah awal yang dilakukan adalah membuat plot data asli, grafik fungsi Autokorelasi $(A C F)$ dan fungsi Autokorelasi Parsial $(P A C F)$ yang digunakan untuk menentukan kestasioneran data dalam mean dan varians.

\section{Estimasi Parameter}

Tahap selanjutnya setelah model awal teridentifikasi adalah mencari estimasi terbaik untuk parameter dalam model itu. Metode yang digunakan untuk menentukan model terbaik adalah metode MSE (Mean Square Error). 


\section{Diagnosis Model}

Diagnosa model dilakukan dengan menguji residual dari model, yaitu uji independensi residual dan uji kenormalan residual.

4. Peramalan

Menentukan peramalan atau peramalan data dengan menggunakan metode ARIMA

\section{HASIL DAN PEMBAHASAN}

Dalam penelitian ini model time series dapat dibuat dari data jumlah penumpang yang diambil dari tahun 2010 sampai dengan 2016 dengan menggunakan model ARIMA. Adapun langkah-langkah pada analisis model ARIMA menggunakan bantuan Sofware Minitab. Data yang digunakan berupa data jumlah keberangkatan pesawat terbang di Bandar Internasional Pattimura Ambon, sebagai berikut:

Tabel 1. Data penumpang pesawat di Bandar Udara Internasional Pattimura Ambon

\begin{tabular}{|l|c|c|c|c|c|c|c|}
\hline \multirow{2}{*}{ BULAN } & $\begin{array}{c}\text { TAHUN } \\
\mathbf{2 0 1 0}\end{array}$ & $\begin{array}{c}\text { TAHUN } \\
\mathbf{2 0 1 1}\end{array}$ & $\begin{array}{c}\text { TAHUN } \\
\mathbf{2 0 1 2}\end{array}$ & $\begin{array}{c}\text { TAHUN } \\
\mathbf{2 0 1 3}\end{array}$ & $\begin{array}{c}\text { TAHUN } \\
\mathbf{2 0 1 4}\end{array}$ & $\begin{array}{c}\text { TAHUN } \\
\mathbf{2 0 1 5}\end{array}$ & $\begin{array}{c}\text { TAHUN } \\
\mathbf{2 0 1 6}\end{array}$ \\
\hline Januari & 27102 & 27817 & 39639 & 44938 & 47.280 & 52026 & 53828 \\
Februari & 25176 & 26198 & 36533 & 32591 & 41.345 & 43.820 & 52388 \\
Maret & 28574 & 25409 & 39732 & 43446 & 47.272 & 40.644 & 49306 \\
April & 28389 & 22672 & 36012 & 39523 & 40.037 & 43.012 & 48351 \\
Mei & 30332 & 35385 & 40340 & 31257 & 46.775 & 48.727 & 52738 \\
Juni & 32373 & 33253 & 48272 & 40866 & 47.377 & 49.718 & 50311 \\
Juli & 29941 & 43040 & 47297 & 41158 & 40.725 & 56.678 & 56058 \\
Agustus & 20351 & 23170 & 44049 & 46781 & 52.306 & 60.496 & 57309 \\
September & 26681 & 41446 & 43803 & 51362 & 47.440 & 54.389 & 51626 \\
Oktober & 27191 & 27220 & 49892 & 52592 & 51.504 & 57.742 & 54579 \\
November & 31554 & 38622 & 43923 & 49169 & 43.654 & 56.435 & 51250 \\
Desember & 27984 & 39009 & 42169 & 51083 & 58.517 & 64.628 & 60473 \\
\hline
\end{tabular}

Langkah awal dalam ARIMA adalah membuat plot data peramalan jumlah penumpang kedatangan pesawat terbang dalam bentuk plot data untuk mengetahui gerakan perubahan jumlah kedatangan pesawat terbang terhadap waktu. Berikut ini adalah data plot jumlah kedatangan pesawat dari tahun 2010-2016.

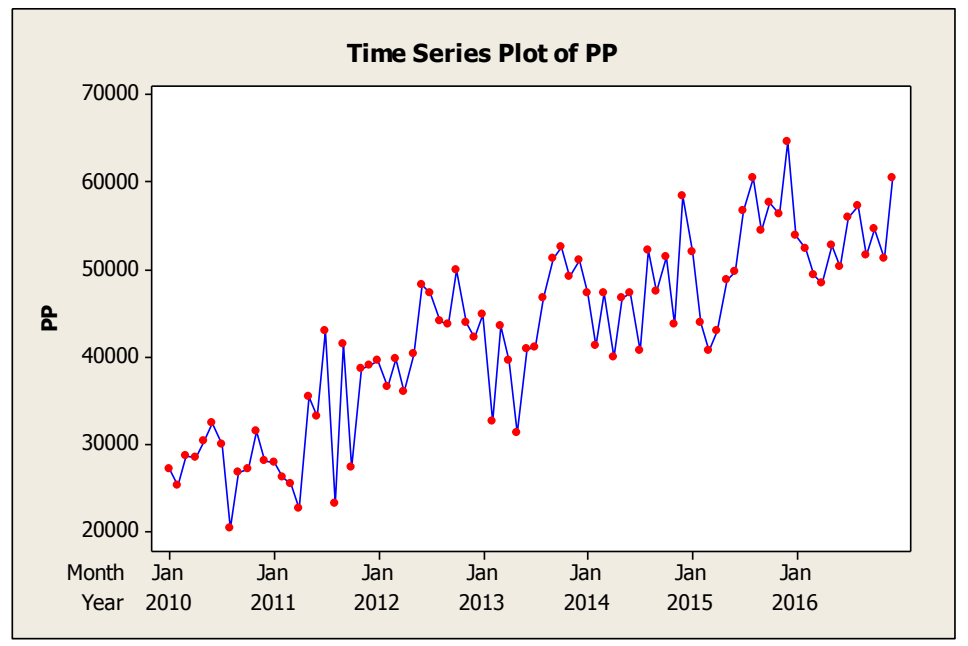

Gambar 1. Plot data penumpang

Berdasarkan Gambar 1, dapat diketahui bahwa plot yang terjadi pada data jumlah penumpang kedatangan pesawat terbang adalah data dengan trend acak sehingga data tersebut merupakan data non musiman. 


\subsection{Peramalan ARIMA BOX-JENKINS}

Pada bagian ini dibahas mengenai tahapan dari metode ARIMA BOX-JENKINS. 4 tahapan dalam menggunakan metode ARIMA BOX-JENKINS yaitu identifikasi model, estimasi parameter model, diagnosis model, dan peramalan.

\section{a. Identifikasi Model}

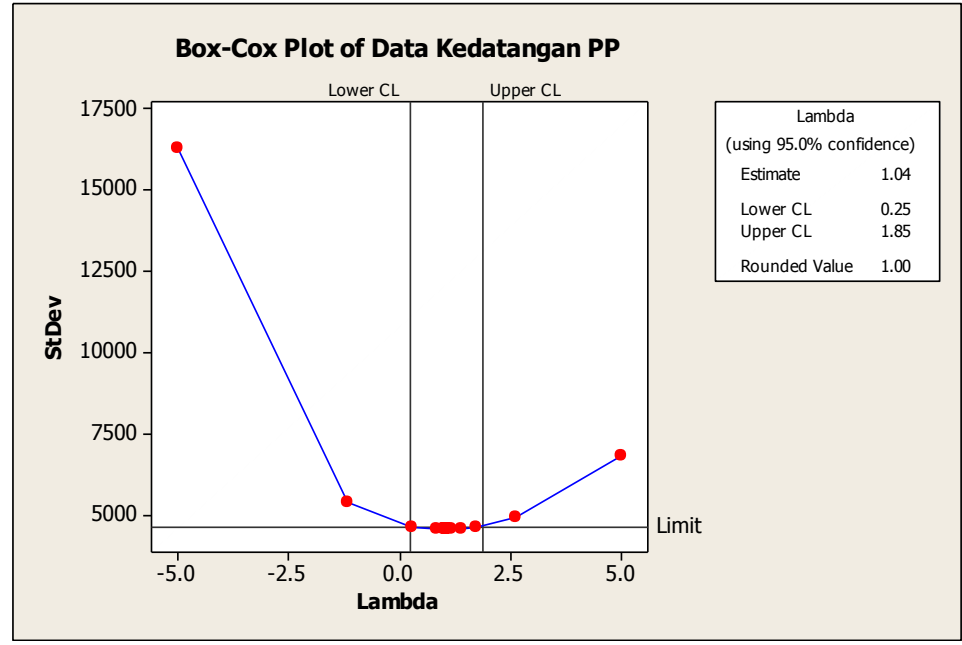

Gambar 2. Transformasi Box-Cox

Berdasarkan Gambar 2, Transformasi Box-Cox di atas dapat diketahui bahwa data jumlah kedatangan penumpang pesawat terbang pada penerbangan domestik di Bandar Udara Internasional Pattimura Ambon dalam periode bulanan mulai dari Januari 2010 sampai Desember 2016 telah stasioner terhadap varian, hal ini dapat dilihat berdasarkan nilai rounded value yang sama dengan 1.

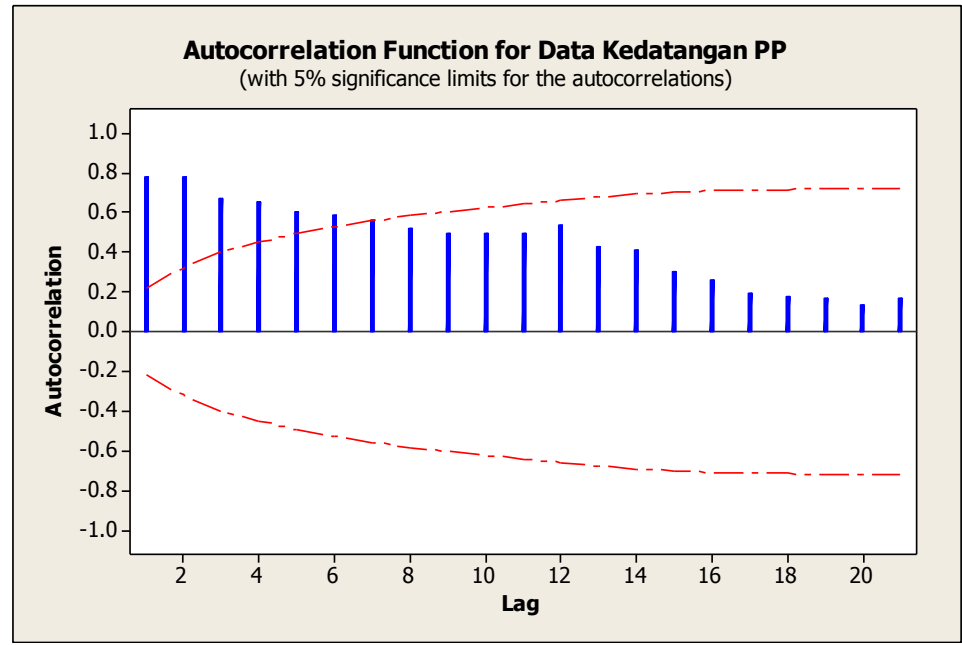

Gambar 3. ACF belum Stasioner

Pada Gambar 3 menunjukan bahwa data belum stasioner terhadap rata-rata, hal ini dapat dilihat dari lag yang keluar dari garis stasioner yang lebih dari 3. untuk membuat data menjadi stasioner terhadap rata-rata maka kita harus melakukan proses differencing. 


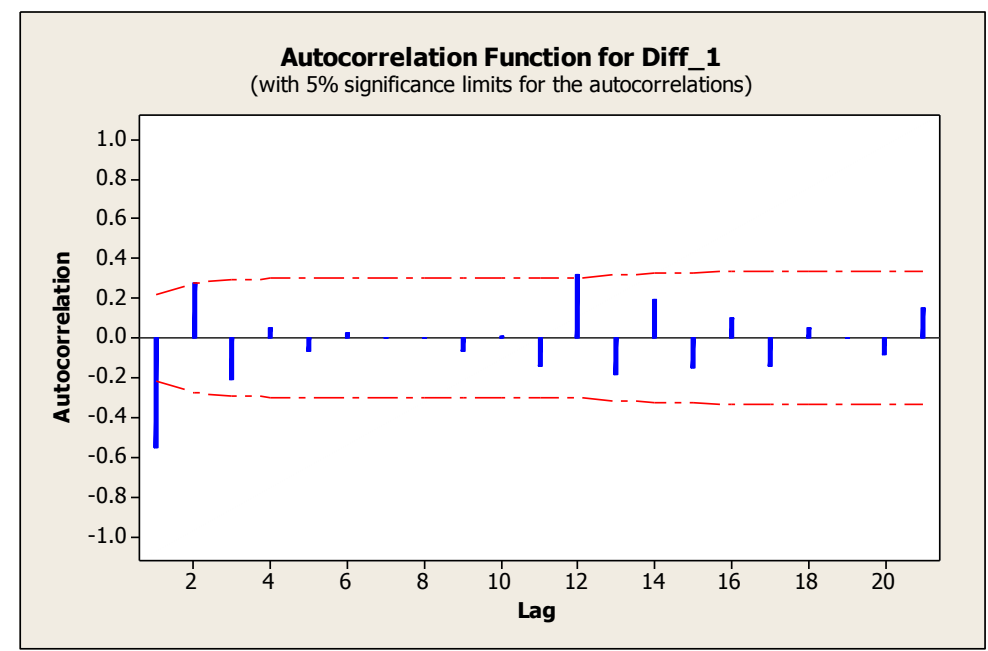

Gambar 4. ACF setelah differencing

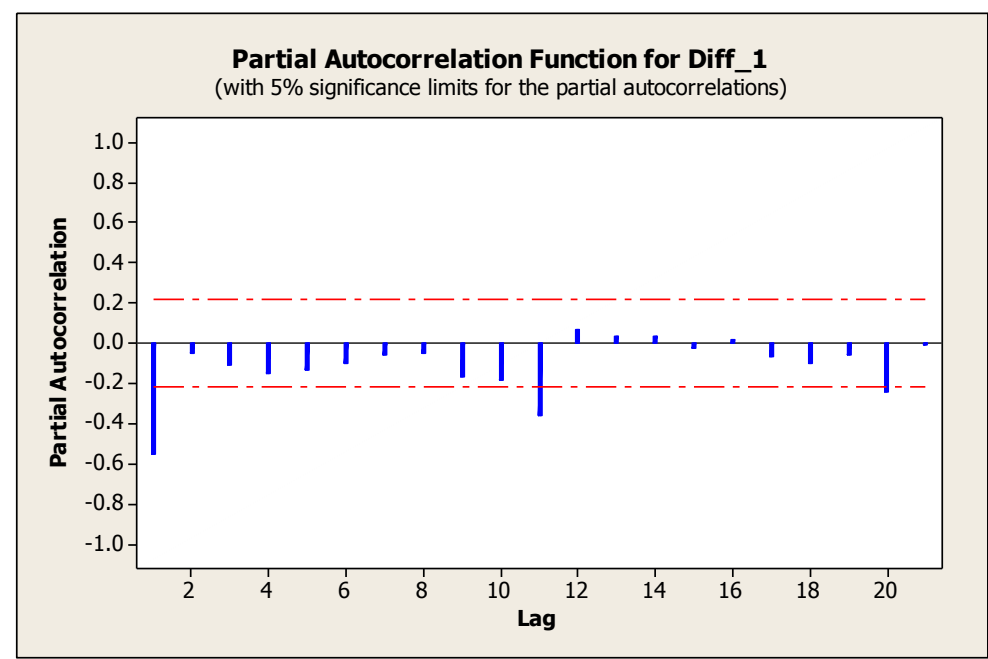

Gambar 5. PACF setelah differencing

Setelah melakukan proses differencing pada Gambar 4 dan Gambar 5 dapat dilihat bahwa lag yang keluar dari garis stasioner tidak lebih dari 3, sehingga dapat dikatakan data jumlah kedatangan penumpang pesawat pada periode bulan Januari 2010 sampai Desember 2016 telah stasioner terhadap rata-rata.

Tabel 2. Nilai ACF dan PACF hasil differencing

\begin{tabular}{|c|c|c|c|c|c|c|c|}
\hline \multicolumn{5}{|c|}{ Data ACF } & \multicolumn{4}{c|}{ Data PACF } \\
\hline Lag & ACF & Lag & ACF & Lag & PACF & Lag & PACF \\
\hline 1 & -0.55442 & 12 & 0.319427 & 1 & -0.55442 & 12 & 0.067382 \\
2 & 0.275274 & 13 & -0.18702 & 2 & -0.04635 & 13 & 0.03565 \\
3 & -0.20978 & 14 & 0.194701 & 3 & -0.10966 & 14 & 0.037448 \\
4 & 0.052477 & 15 & -0.15408 & 4 & -0.14765 & 15 & -0.02444 \\
5 & -0.06711 & 16 & 0.096732 & 5 & -0.13462 & 16 & 0.015907 \\
6 & 0.022832 & 17 & -0.13846 & 6 & -0.10255 & 17 & -0.06889 \\
7 & 0.002882 & 18 & 0.052896 & 7 & -0.05487 & 18 & -0.10103 \\
8 & -0.001 & 19 & -0.00406 & 8 & -0.053 & 19 & -0.05667 \\
9 & -0.07002 & 20 & -0.08529 & 9 & -0.1652 & 20 & -0.24445 \\
10 & 0.005463 & 21 & 0.149833 & 10 & -0.18094 & 21 & -0.00964 \\
11 & -0.14138 & & & 11 & -0.35849 & & \\
\hline
\end{tabular}

Dari plot ACF dan PACF pada Gambar 4 dan Gambar 5 hasil dari proses differencing terlihat bahwa ACF dan PACF sudah signifikan pada semua lag. Dengan differencing orde 1 maka model awal yang didapat adalah ARIMA(1,1,3). 


\section{b. Estimasi Parameter Model}

Setelah mendapatkan model ARIMA $(1,1,3)$ sebagai model awal selanjutnya akan dilakukan pemilihan model terbaik dengan menggunakan metode trial and error yang dapat dilihat pada tabel 3 sebagai berikut:

Tabel 3. Model trial and error

\begin{tabular}{|c|c|c|c|}
\hline No & Model Arima & Signifikan parameter & Nilai MSE \\
\hline 1 & ARIMA $(0,1,1)$ & Ya & 30185648 \\
2 & ARIMA $(0,1,2)$ & Ya & 29528114 \\
3 & ARIMA $(0,1,3)$ & Ya & 26178364 \\
4 & ARIMA $(1,1,0)$ & Ya & 30356433 \\
5 & ARIMA $(2,1,0)$ & Tidak & - \\
6 & ARIMA $(3,1,0)$ & Tidak & - \\
7 & ARIMA $(1,1,1)$ & Tidak & - \\
8 & ARIMA $(1,1,2)$ & Tidak & - \\
9 & ARIMA $(1,1,3)$ & Ya & 26435095 \\
10 & ARIMA $(2,1,1)$ & Tidak & - \\
11 & ARIMA $(2,1,2)$ & Ya & 26810081 \\
12 & ARIMA $(2,1,3)$ & Tidak & - \\
13 & ARIMA (3,1, & Ya & 27248921 \\
14 & ARIMA (3,1,2) & Tidak & - \\
15 & ARIMA (3,1,3) & Tidak & - \\
\hline
\end{tabular}

Berdasarkan tabel 3 terlihat bahwa model terbaik untuk data peramalan jumlah penumpang pesawat terbang di pintu kedatangan Bandar Udara Pattimura Ambon adalah ARIMA $(0,1,3)$ memiliki nilai MSE sebesar 26178364 yang dapat dilihat pada hasil output software Minitab, sebagai berikut:

MODEL ARIMA $(0,1,3)$

\begin{tabular}{cccccc} 
Iteration & SSE & \multicolumn{4}{c}{ Parameters } \\
0 & 3274127320 & 0.100 & 0.100 & 0.100 & 402.160 \\
1 & 2848964522 & 0.250 & 0.105 & 0.110 & 377.204 \\
2 & 2524875244 & 0.400 & 0.071 & 0.135 & 362.256 \\
3 & 2283115647 & 0.550 & -0.003 & 0.198 & 356.776 \\
4 & 2112760626 & 0.700 & -0.108 & 0.310 & 368.876 \\
5 & 2075810260 & 0.728 & -0.103 & 0.333 & 375.554 \\
6 & 2073069952 & 0.740 & -0.113 & 0.342 & 376.301 \\
7 & 2070571483 & 0.744 & -0.126 & 0.344 & 366.643 \\
8 & 2069884671 & 0.746 & -0.125 & 0.346 & 370.020 \\
9 & 2069839884 & 0.745 & -0.127 & 0.345 & 367.485 \\
10 & 2069484247 & 0.747 & -0.130 & 0.349 & 371.981 \\
11 & 2069433873 & 0.748 & -0.132 & 0.347 & 367.623 \\
12 & 2069048749 & 0.748 & -0.131 & 0.348 & 369.723 \\
13 & 2069023466 & 0.748 & -0.131 & 0.348 & 369.497
\end{tabular}

Final Estimates of Parameters

$\begin{array}{ccccc}\text { Type } & \text { Coef } & \text { SE Coef } & \text { T } & \boldsymbol{P} \\ \text { MA 1 } & 0.7482 & 0.1102 & 6.79 & 0 \\ \text { MA 2 } & -0.1309 & 0.1310 & -1.00 & 0.321 \\ \text { MA 3 } & 0.3480 & 0.1104 & 3.15 & 0.002 \\ \text { Constant } & 369.5000 & 50.3500 & 7.34 & 0\end{array}$

Differencing: 1 regular difference

Number of observations : Original series 84, after differencing 83

Residuals: $\quad S S=2068090720$ (backforecasts excluded)

$M S \quad=26178364 D F=79$ 
Modified Box-Pierce (Ljung-Box) Chi-Square statistic

$\begin{array}{lcccc}\text { Lag } & 12 & 24 & 36 & 48 \\ \text { Chi-Square } & 12.6 & 20.5 & 29.5 & 37.9 \\ \text { DF } & 8 & 20 & 32 & 44 \\ P \text {-Value } & 0.125 & 0.429 & 0.594 & 0.73\end{array}$

Berdasarkan hasil output Minitab diatas dapat dilihat bahwa nilai koefisien parameter untuk ARIMA $(0,1,3)$ adalah:

Tabel 4. Estimasi parameter model ARIMA(0,1,3)

\begin{tabular}{|c|c|c|}
\hline Parameter & Koefisien & p-value \\
\hline MA (1) / $\boldsymbol{\theta}_{\mathbf{1}}$ & 0.7482 & 0.000 \\
\hline MA (2) $/ \boldsymbol{\theta}_{\mathbf{2}}$ & -0.1309 & 0.321 \\
\hline MA (3) / $\boldsymbol{\theta}_{\mathbf{3}}$ & 0.3480 & 0.002 \\
\hline Konstanta / $\boldsymbol{\beta}_{\mathbf{0}}$ & 369.5000 & 0.000 \\
\hline
\end{tabular}

Dari Tabel 4 dapat dilihat bahwa hasil estimasi parameter pada model ARIMA $(0,1,3)$ adalah $\theta_{1}=0.7482$, $\theta_{2}=-0.1309, \theta_{3}=0.3480$ dan $\beta_{0}=369.5$. Selanjutnya akan dilakukan uji signifikansi parameter tersebut dengan menggunakan nilai $p$-value.

Berdasarkan hasil yang diperoleh pada tahap estimasi parameter, parameter yang signifikan dalam model ARIMA $(0,1,3)$ adalah $\theta_{1}=0.7482, \theta_{3}=0.3480$ dan $\beta_{0}=369.5$. Dengan menggunakan model matematis untuk Moving Average orde 2 atau MA(2) sebagai berikut:

$$
Z_{t}=e_{t}-\theta_{1} e_{t-1}-\theta_{2} e_{t-2}
$$

Maka model ARIMA $(0,1,3)$ adalah sebagai berikut:

$$
Z_{t}=e_{t}-0.7482 e_{t-1}-0.3480 e_{t-2}
$$

\section{c. Diagnosis Model}

Diagnosis model ditentukan dengan uji independensi residual dan normalitas residual.

\section{- Uji Independensi Residual}

Uji independensi residual digunakan untuk mendeteksi ada tidaknya korelasi residual antar lag. Langkah langkah dalam melakukan uji independensi residual adalah

Hipotesis

$$
\begin{aligned}
& H_{0}: \rho_{1}=\rho_{2} \ldots=\rho_{k}=0 \text { (residual independent) } \\
& H_{1}: \text { minimal ada satu } \rho_{i} \neq 0, \text { untuk } \mathrm{i}=1,2, \ldots, K
\end{aligned}
$$

Taraf signifikansi

$$
\alpha=0.05
$$

\section{Menentukan kriteria keputusan}

Uji Ljung-Box mengikuti distribusi $\chi^{2} . H_{0}$ ditolak jika, $p$-value $<\alpha$ atau $Q_{\text {hitung }}>\chi_{(\alpha-d f)}^{2}$ dengan $p$ adalah banyak parameter $A R$ dan $q$ adalah banyaknya parameter MA, artinya $\left\{e_{t}\right\}$ merupakan suatu barisan yang dependent.

Tabel 5. Modified box-pierce (ljung-box) chi-square statistik

\begin{tabular}{|c|c|c|c|}
\hline Lag $(\boldsymbol{K})$ & $\boldsymbol{d} \boldsymbol{f}(\boldsymbol{K}-\boldsymbol{k})$ & $\chi_{(\alpha-d f)}^{2}$ & $\boldsymbol{p}$-value \\
\hline 12 & 8 & 12,6 & 0,125 \\
\hline 24 & 20 & 20,5 & 0,429 \\
\hline 36 & 32 & 29,5 & 0,594 \\
\hline 48 & 44 & 37,9 & 0,730 \\
\hline
\end{tabular}


Dari Tabel 5, dapat disimpulkan bahwa residual dari lag 12 sampai lag 48 tidak terjadi korelasi antar lag, hal ini dapat dilhat berdasarkan nilai p-value yaitu pada lag 12 sampai lag 48 semua nilai $p$-value> 0,05. Sehingga dapat disimpulkan bahwa residual telah memenuhi asumsi independent.

\section{- Uji Kenormalan Residual}

Uji kesesuaian model untuk membuktikan model sementara yang telah ditetapkan cukup memadai dengan menggunakan analisis galat untuk memenuhi asumsi kenormalan model. Uji kenormalan model dilakukan dengan uji Kolmogorov Smirnov.

Hipotesis:

$H_{0}$ : data berdistribusi normal

$H_{1}$ : data tidak berdistribusi normal

Uji normalitas dilakukan dengan menggunakan software Minitab.

\section{Kriteria keputusan:}

Tolak $H_{0}$ jika nilai signifikansi $<\alpha$.

Selain melakukan uji kolmogarov smirnov, dilakukan uji white noise untuk memenuhi asumsi tidak ada auto korelasi residual dengan menggunakan statistic uji Ljung box.

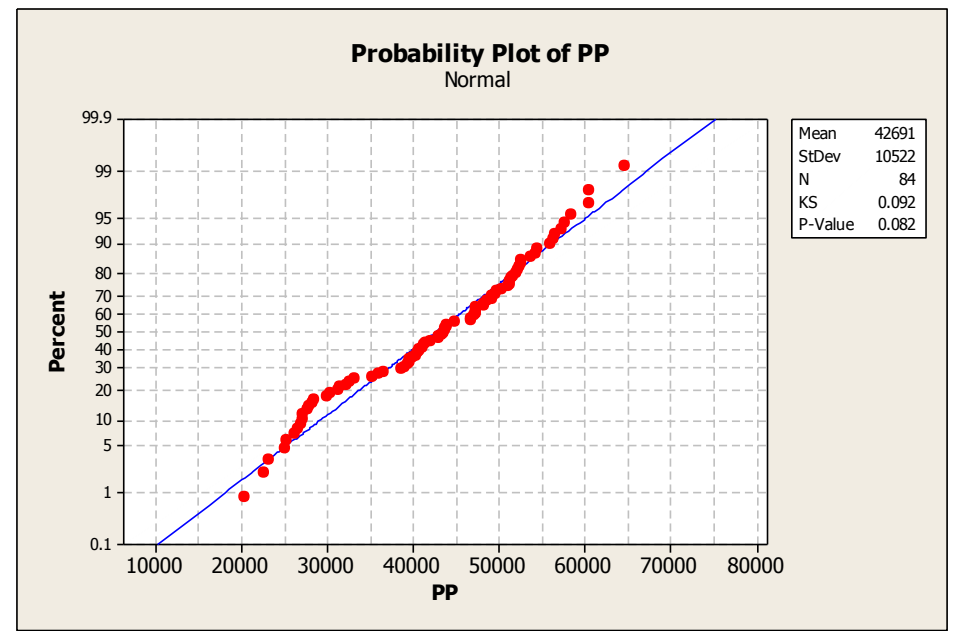

Gambar 6. Plot kolmogorov smirnov

Berdasarkan Gambar 6, p-value > 0.05 maka model ARIMA $(0,1,3)$ memenuhi asumsi normalitas residual. Selanjutnya dilakukan peramalan dengan menggunakan model ARIMA $(0,1,3)$.

\section{d. Peramalan}

Berdasarkan hasil diagnosis model, model ARIMA $(0,1,3)$ merupakan model terbaik, juga telah memenuhi asumsi independent dan asumsi normalitas sehingga model ini dapat digunakan untuk peramalan kedatangan penumpang pesawat terbang pada penerbangan domestik di Bandar Udara Internasional Pattimura Ambon dalam periode bulanan mulai dari Januari 2010 sampai Desember 2016, untuk 12 bulan kedepannya. 
Tabel 6. Data peramalan penumpang pesawat terbang di kota Ambon

\begin{tabular}{|l|c|c|c|}
\hline \multicolumn{1}{|c|}{ Bulan } & \multicolumn{1}{c|}{$\begin{array}{c}\text { Data } \\
\text { Ramalan }\end{array}$} & $\begin{array}{c}\text { Data } \\
\text { Aktual }\end{array}$ & $\begin{array}{c}\text { Data } \\
\text { Eror }\end{array}$ \\
\hline January 2017 & 57812,9 & 47774 & -2811.17 \\
\hline February 2017 & 60001,4 & 39309 & 39309 \\
\hline Maret 2017 & 58881,8 & 44141 & 44141 \\
\hline April 2017 & 59251,3 & 45104 & 45104 \\
\hline Mei 2017 & 59620,8 & 47884 & 47884 \\
\hline Juni 2017 & 59990,3 & 45450 & 45450 \\
\hline Juli 2017 & 60359,8 & 49594 & 49594 \\
\hline Agustus 2017 & 60729,3 & 45000 & 45000 \\
\hline September 2017 & 61098,8 & 51562 & 51562 \\
\hline Oktober 2017 & 61468,3 & 64954 & 64954 \\
\hline November 2017 & 61837,8 & 53833 & 53833 \\
\hline Desember 2017 & 62207,3 & 72417 & 72417 \\
\hline
\end{tabular}

Berdasarkan Tabel 6, Dapat disimpulkan bahwa hasil ramalan jumlah penumpang pesawat terbang di Kota Ambon pada bulan Januari 2017 sampai Desember 2017 mengalami peningkatan jumlah penumpang tiap bulannya kecuali pada bulan Desember 2017 dengan jumlah penumpang paling sedikit terjadi pada sebesar 62207,3 dan data aktualnya adalah 72417 .

\section{KESIMPULAN}

Berdasarkan hasil analisis pada pembahasan dapat diperoleh simpulan sebagai berikut:

1. Model ARIMA terbaik yang digunakan dalam melakukan peramalan kedatangan penumpang pesawat terbang pada penerbangan domestik di Bandar Udara Internasional Pattimura Ambon adalah model ARIMA $(0,1,3)$ dengan koefisien parameter $\theta_{1}=0.7482, \theta_{3}=0.3480$ dan $\beta_{0}=369.5$. Sehingga model matematis untuk ARIMA $(0,1,3)$ adalah

$$
Z_{t}=e_{t}-0.7482 e_{t-1}-0.3480 e_{t-2}
$$

2. Hasil ramalan jumlah penumpang pesawat terbang di kota ambon pada bulan Januari 2017 sampai Desember 2017 mengalami peningkatan jumlah penumpang tiap bulannya kecuali pada bulan Desember 2017.

\section{DAFTAR PUSTAKA}

[1] Anonim, (http://apriapita.blogspot.co.id/2016/06/transportasi-udara.html),04 Oktober 2017, Pada Pukul 10:27 WIT, 2017.

[2] Anomim, Statistik Transportasi Propinsi Maluku: BPS Maluku, 2015.

[3] Anderson O. D," Time Series Analysis and Forecasting -The Box-Jenkins Approach", London: Butterworths., 1976.

[4] F. I. Durrah, Yulia, T. P. Parhusip, A. Rusyana, "Peramalan Jumlah Penumpang Pesawat Di Bandara Sultan Iskandar Muda Dengan Metode SARIMA (Seasonal Autoregressive Integrated Moving Average)," Journal of Data Analysis, Vol.1, No.1, p. 01-11, Juni 2018.

[5] Hendikawati,"Bahan Ajar Analisis Runtun Waktu”, Semarang : Universitas Negeri Semarang, 2014.

[6] J. Iqbalullah, W. S. Winahju , "Peramalan Jumlah Penumpang Pesawat Terbang di Pintu Kedatangan Bandar Udara Internasional Lombok dengan Metode ARIMA Box-Jenkins, ARIMAX, dan Regresi Time Series," JURNAL SAINS DAN SENI POMITS, Vol. 3, No. 2, p. D-212- D-217, ISSN: 2337-3539, 2014.

[7] Makridakis, S., Wheelwright, Victor, E., dan McGee., "Metode dan Aplikasi Peramalan", Jakarta: Erlangga, 1999. 
[8] N. F. Jannah, M. B. I. Fuady, S. Prasetianto, "Peramalan Jumlah Penumpang Bandara I Gusti Ngurah Rai Dengan Menggunakan Metode Autoregressive Integrated Moving Average(Arima)," Konferensi Nasional Penelitian Matematika dan Pembelajarannya II (KNPMP II), ISSN: 2502-6526, , p. 117-123, Maret 2017.

[9] R. S. Faustina, A. Agoestanto, P. Hendikawati, "Model Hybrid Arima-Garch Untuk Estimasi Volatilitas Harga Emas Menggunakan Software R,” UNNES Journal of Mathematics,p-ISSN 2252-6943, Vol.6, No.1, p. 11-24, Mei 2017.

[10] Santoso, Singgih, "Business Forecaseting Metode Peramalan Bisnis Masa Kini dengan Minitab dan SPSS", Jakarta: PT.Elex Media Komputindo, 2009.

[11] S. Aziz, A. Sayuti, Mustakin,'Penerapan Metode ARIMA untuk Peramalan Pengunjung Perpustakaan UIN Suska Riau,"Seminar Nasional Teknologi Informasi, Komunikasi dan Industri (SNTIKI), ISSN: 2579-5406, pp. 186193, Mei 2017.

[12] S. Dheviani, Wardono, P. Hendikawati, "Peramalan Banyaknya Penumpang Di Bandar Udara Internasional Ahmad Yani Semarang Dengan Mempertimbangkan Special Event," PRISMA Prosiding Seminar Nasional Matematika, Vol. 1, p. 434-444, 2018. 